\title{
PENGARUH KEPRIBADIAN ORANG MELAYU TERHADAP MOTIVASI BERWIRAUSAHA PADA USAHA MIKRO KECIL DAN MENENGAH (UMKM) DI KECAMATAN BENGKALIS
}

\author{
Wan Muhammad Fariq \\ Saifullah \\ Imam Fakhruddin \\ Sekolah Tinggi Agama Islam Negeri (STAIN) Bengkalis \\ one.fariq1@gmail.com
}

\begin{abstract}
Abstrak
Penelitian ini dilakukan pada Usaha Mikro Kecil dan Menengah pada Kecamatan Bengkalis. Sampel dalam penelitian ini yaitu merupakan pengusaha pada Usaha Mikro Kecil dan Menengah di Kecamatan Bengkalis. Kuesioner ini terbagi dalam dua bagian, yang pertama adalah bagaimana respon pengusaha tentang kepribadiannya dan yang kedua adalah respon pengusaha mengenai motivasinya dalam melakukan usahanya yang berjumlah 75 orang. Sedangkan Populasinya adalah seluruh pengusaha UMKM di Kecamatan Bengkalis. Hasil penelitian dapat disimpulkan bahwa kepribadian orang Melayu di Kecamatan Bengkalis mempunyai kepribadian yang baik denga rata-rata 3,82. Sedangkan motivasi berwirausaha di Kecamatan Bengkalis dalam mengembangkan usaha UMKM termasuk dalam katagori baik dengan rata-rata 3,83. Adapun hasil analisis regresi sederhana diketahui nilai signifikasi dari tabel adalah 0,08>0,05 dan thitung 2,739>t tabel 1,665, maka terdapat pengaruh kepribadian orang melayu terhadap motivasi berwirausaha dalam Usaha Mikro, Kecil dan Menengah tetapi pengaruhnya tidak signifikan.
\end{abstract}

Kata Kunci: Kepribadian Orang Melayu dan Motivasi Kewirausahaan 


\section{A. PENDAHULUAN}

Bengkalis merupakan daerah dataran rendah dengan ketinggian ratarata sekitar 2-6,1 m dari permukaan laut. Sebagian besar merupakan tanah organosol, yaitu jenis tanah yang banyak mengandung bahan organik. Di daerah ini juga terdapat beberapa sungai, tasik (danau) serta 24 Pulau besar dan kecil. Beberapa di antara pulau besar itu adalah Pulau Rupat $\left(1.524,84 \mathrm{~km}^{2}\right)$ dan Pulau Bengkalis $\left(938,40 \mathrm{~km}^{2}\right)$. Bengkalis mempunyai klim tropis yang sangat dipengaruhi oleh iklim laut dengan temperatur $26{ }^{\circ} \mathrm{C}-32{ }^{\circ} \mathrm{C}$. Musim hujan biasa terjadi sekitar bulan September - Januari dengan curah hujan rata-rata berkisar antara 809$4.078 \mathrm{~mm} /$ tahun. Periode musim kering (musim kemarau) biasanya terjadi antara bulan Februari hingga Agustus.

Secara Administrasi Pemerintah, Kabupaten Bengkalis terbagi dalam 8 Kecamatan, 102 Kelurahan/Desa dengan luas wilayah $7.793,93 \mathrm{~km}^{2}$. Tercatat jumlah penduduk Kabupaten Bengkalis 498.335 jiwa dengan sifatnya yang heterogen, mayoritas penduduknya adalah penganut agama Islam. Disamping suku Melayu yang merupakan mayoritas penduduk, juga terdapat suku-suku lainnya seperti: suku Minang, suku Jawa yang mayoritas tinggal di Desa Pedekik, Wonosari, suku Bugis, suku Batak, etnis Tionghoa dan sebagainya. Bengkalis sebagai ibu kota kabupaten dikenal juga dengan julukan Kota Terubuk, karena daerah ini adalah penghasil telur ikan Terubuk yang sangat disukai masyarakat karena rasanya yang amat lezat dan tentu saja menyebabkan harga telur ikan Terubuk menjadi amat mahal.

\section{Tabel 1.1}

\section{Jumlah Penduduk dan Laju Pertumbuhan Penduduk Kabupaten Bengkalis} pada Tahun 2010 dan 2015

\begin{tabular}{|l|c|c|c|}
\hline \multicolumn{1}{|c|}{ Kecamatan } & \multicolumn{2}{|c|}{$\begin{array}{c}\text { Jumlah Penduduk } \\
\text { (Population) }\end{array}$} & $\begin{array}{c}\text { Laju Pertumbuhan Penduduk } \\
\text { per Tahun (\%) }\end{array}$ \\
\hline Subdistrict & 2010 & 2015 & Yearly Population Growth Rate (\%) \\
\hline 1. Mandau & 220.335 & 239.513 & 1.68 \\
\hline 2. Pinggir & 79.056 & 86.535 & 1.82 \\
\hline 3. Bukit Batu & 30.254 & 32.840 & 1.65 \\
\hline 4. Siak Kecil & 18.730 & 20.220 & 1.54 \\
\hline 5. Rupat & 30.600 & 33.063 & 1.56 \\
\hline 6. Rupat Utara & 13.077 & 14.201 & 1.66 \\
\hline
\end{tabular}




\begin{tabular}{|l|c|c|c|}
\hline 7. Bengkalis & 72.472 & 78.571 & 1.63 \\
\hline 8. Bantan & 36.111 & 39.044 & 1.57 \\
\hline Jumlah & $\mathbf{5 0 0 . 6 3 5}$ & $\mathbf{5 4 3 . 9 8 7}$ & 1.67 \\
\hline
\end{tabular}

Sumber: Badan Pusat Statistik Kabupaten Bengkalis

Keadaan penduduk Bengkalis mengalami peningkatan pada setiap tahunnya. Laju pertumbuhan penduduk di Kabupaten Bengkalis yang terus meningkat dapat dilihat dari tabel jumlah penduduk dan laju pertumbuhan penduduk dari tahun 2010 sampai tahun 2015 yang di peroleh dari jumlah penduduk dari 8 Kecamatan yang berada di Kabupaten Bengkalis. Berdasarkan tabel diperoleh data jumlah penduduk pada tahun 2010 berjumlah 500.635 dan meningkat menjadi 543.987 jiwa pada tahun 2015 . Jadi dapat disimpulkan bahwa terjadi peningkatan 43.352 jiwa pada 5 tahun terakhir dengan persentase laju pertumbuhan penduduknya sebesar $1,67 \%$.

\section{Tabel 1.2}

\section{Presentase Penduduk Miskin dan Garis Kemiskinan Kabupaten Bengkalis}

\begin{tabular}{|c|c|c|}
\hline Tahun & $\begin{array}{c}\text { Miskin (\%) } \\
\text { Poor Population (\%) }\end{array}$ & $\begin{array}{c}\text { Garis Kemiskinan } \\
\text { Poverty Line }\end{array}$ \\
\hline 2008 & 8.94 & 255,670 \\
2009 & 7.91 & 295,867 \\
2010 & 8.25 & 325,485 \\
2011 & 6.72 & 349,770 \\
2012 & 6.76 & 367,743 \\
2013 & 7.57 & 388,671 \\
2014 & 7.20 & 405,945 \\
\hline
\end{tabular}

Sumber: Badan Pusat Statistik Kabupaten Bengkalis

Berdasarkan tabel 1.2 di atas dapat di lihat bahwa ada persentase penduduk miskin d Kabupaten Bengkalis dengan interval waktu dari tahun 2008 sampai 2014 mengalami fluktuatif. Pada tahun 2008 persentase penduduk miskin berada di angka 8,94\% dan menurun menjadi 7,91\% pada tahun 2009 dan kembali naik angka kemiskinannya pada tahun 2010 menjadi 8,25\%, dan pada tahun 2011 dan 2012 angka kemiskinan 
kembali menurun, berada di bawah angka 7\%. Sedangkan pada tahun 2013 dan 2014 angka kemiskinan kembali naik dengan persentasenya di atas $7 \%$.

Salah satu faktor kemiskinan adalah faktor kultural, dijelaskan bahwa kondisi atau kualitas budaya yang menyebabkan kemiskinan. Faktor ini secara khusus sering menunjuk pada konsep kemiskinan yang menghubungkan kemiskinan dengan kebiasaan hidup atau mentalitas. Penelitian Oscar Lewis di Amerika Latin menemukan bahwa orang miskin memiliki sub-kultur atau kebiasaan sendiri, yang berbeda dengan masyarakat kebanyakan. ${ }^{1}$ sikap-sikap negatif seperti malas, fatalism atau menyerah kepada nasib, tidak memiliki jiwa wirausaha, dan kurang menghormati etos kerja, misalnya sering ditemukan pada orang-orang miskin.

Berkaitan dengan perbandingan jumlah penduduk dan jumlah pengusaha yang berada di Kecamatan Bengkalis berbanding terbalik, data Usaha Mikro, Kecil dan Menengah dapat kita lihat pada table berikut ini.

\section{Tabel 1.3}

Daftar UMKM perbidang usaha UMKM

Kecamatan Bengkalis tahun 2014 - 2018

\begin{tabular}{|c|c|c|c|c|c|c|c|}
\hline \multirow{2}{*}{ NAMA } & \multicolumn{5}{|c|}{ Tahun } & \multirow{2}{*}{ Jum } & \multirow{2}{*}{ Sat } \\
\hline & 2014 & 2015 & 2016 & 2017 & 2018 & & \\
\hline \multicolumn{8}{|c|}{ A. Jumlah UMKM Bidang Kuliner } \\
\hline 1. Jumlah Usaha Mikro & 197 & 197 & 197 & 197 & 50 & 838 & Usaha \\
\hline 2. Jumlah Usaha Kecil & 10 & 10 & 10 & 10 & 5 & 45 & Usaha \\
\hline $\begin{array}{l}\text { 3. Jumlah Usaha } \\
\text { Menengah }\end{array}$ & 3 & 3 & 3 & 3 & 0 & 12 & Usaha \\
\hline \multicolumn{8}{|c|}{ B. Jumlah UMKM Bidang Fasion,Tenun } \\
\hline 1. Jumlah Usaha Mikro & 188 & 188 & 188 & 188 & 25 & 777 & Usaha \\
\hline 2. Jumlah Usaha Kecil & 8 & 8 & 8 & 8 & 3 & 35 & Usaha \\
\hline $\begin{array}{l}\text { 3. Jumlah Usaha } \\
\text { Menengah }\end{array}$ & 1 & 1 & 1 & 1 & 0 & 4 & Usaha \\
\hline \multicolumn{8}{|c|}{ C. Jumlah UMKM Bidang Otomotif,Las Terali } \\
\hline 1. Jumlah Usaha Mikro & 33 & 33 & 33 & 33 & 5 & 137 & Usaha \\
\hline
\end{tabular}

\footnotetext{
${ }^{1}$ Edi Suharto, Kebijakan Sosial sebagai kebijakan public, (Bandung: Alfabeta 2008), hlm.
} 


\begin{tabular}{|c|c|c|c|c|c|c|c|}
\hline \multirow{2}{*}{ NAMA } & \multicolumn{5}{|c|}{ Tahun } & \multirow{2}{*}{ Jum } & \multirow{2}{*}{ Sat } \\
\hline & 2014 & 2015 & 2016 & 2017 & 2018 & & \\
\hline 2. Jumlah Usaha Kecil & 71 & 71 & 71 & 71 & 0 & 284 & Usaha \\
\hline $\begin{array}{l}\text { 3. Jumlah Usaha } \\
\text { Menengah }\end{array}$ & 0 & 0 & 0 & 0 & 0 & 0 & Usaha \\
\hline \multicolumn{8}{|c|}{ D. Jumlah UMKM Bidang Mubeler dan Anyaman, Pembuatan Batu Batu } \\
\hline 1. Jumlah Usaha Mikro & 153 & 153 & 153 & 0 & 0 & 459 & Usaha \\
\hline 2. Jumlah Usaha Kecil & 29 & 29 & 29 & 0 & 0 & 87 & Usaha \\
\hline $\begin{array}{l}\text { 3. Jumlah Usaha } \\
\text { Menengah }\end{array}$ & 0 & 0 & 0 & 0 & 0 & 0 & Usaha \\
\hline \multicolumn{8}{|c|}{ E. Jumlah UMKM Bidang Perdagangan } \\
\hline 1. Jumlah Usaha Mikro & 2 & 2 & 2 & 0 & 5 & 11 & Usaha \\
\hline 2. Jumlah Usaha Kecil & 10 & 10 & 10 & 0 & 0 & 30 & Usaha \\
\hline $\begin{array}{l}\text { 3. Jumlah Usaha } \\
\text { Menengah }\end{array}$ & 0 & 0 & 0 & 0 & 0 & 0 & Usaha \\
\hline Jumlah & 705 & 705 & 705 & 511 & 93 & 2719 & $\begin{array}{c}\text { Usah } \\
\text { a }\end{array}$ \\
\hline
\end{tabular}

Sumber: Dinas Koperasi UMKM Kabupaten Bengkalis 2018 (Data diolah)

Berdasarkan Tabel 1.3 terjadi penurunan signifikan pada tahun 2017 dan 2018 dari jumlah pengusaha yang resmi terdaftar di Kecamatan Bengkalis, ini di buktikan pengusaha dalam pengurusan surat izin usaha. Dari fenomena di atas maka peneliti tertarik untuk meneliti lebih lanjut mengenai "Pengaruh Kepribadian Orang Melayu Terhadap Motivasi Berwirausaha pada Usaha Mikro Kecil Menengah di Kecamatan Bengkalis".

\section{B. Permasalahan}

\section{Identifikasi Masalah}

a. Wirausaha yang dijalani orang Melayu di Kecamatan Bengkalis lebih banyak pada kategori Mikro dibandingkan dengan Usaha Kecil dan Menengah.

b. Kurang berkembangnya Usaha milik orang Melayu dan kalah saing dengan usaha milik etnis Tionghoa.

c. Rendahnya motivasi masyarakat Melayu di kecamatan Bengkalis dalam berwirausaha. 
2. Batasan Masalah

Agar penelitian ini terarah dan terukur serta dapat mencapai sasaran tujuan, maka dibutuhkan batasan masalah. Hal ini perlu dilakukan agar penelitian ini tidak terlalu luas dalam pembahasannya. Untuk itu, peneliti membatasi penelitian yaitu Pengaruh Kepribadian Orang Melayu Terhadap Motivasi Berwirausaha pada Usaha Mikro Kecil Menengah di Kecamatan Bengkalis.

3. Rumusan Masalah

a. Bagaimanakah Kepribadian Orang Melayu di Kecamatan Bengkalis?

b. Bagaimanakah motivasi orang melayu di Kecamatan Bengkalis dalam mengembangkan Usaha Mikro Kecil dan Menengah?

c. Apakah ada pengaruh kepribadian orang melayu terhadap motivasi berewirausaha dalam Usaha Mikro Kecil dan Menengah di Kecamatan Bengkalis?

\section{Tujuan dan Kegunaan Penelitian}

1. Tujuan Penelitian

Adapun yang menjadi tujuan penelitian ini adalah:

a. Untuk mengetahui kepribadian orang Melayu di Kecamatan Bengkalis.

b. Untuk mengetahui motivasi berwirausaha orang Melayu di Kecamatan Bengkalis dalam mengembangkan Usaha Mikro Kecil dan Menengah.

c. Untuk mengetahui seberapa pengaruh kepribadian orang Melayu terhadap motivasi berwirausaha dalam Usaha Mikro Kecil dan Menengah di Kecamatan Bengkalis.

2. Kegunaan Penelitian

Adapun kegunaan penelitian ini adalah:

a. Penelitian ini diharapkan bermanfaat bagi wirausahawan, stake holder yang berkaitan dengan pelaku usaha dan para akademisi.

b. Secara teoritis penelitian ini sebagai penyumbang dan pengembangan khazanah keilmuan.

c. Memenuhi kewajiban dosen untuk melaksanakan Tri Dharma Perguruan Tinggi dalam bidang penelitian.

d. Penelitian ini diharapkan menjadi rujukan bagi peneliti-peneliti selanjutnya. 


\section{Penegasan Istilah}

1. Melayu

Dalam Wikipedia, dijelaskan bahwa Melayu adalah sebuah kelompok etnis dari orang-orang Austronesia terutama yang menghuni Semenanjung Malaya, Sumatera bagian timur, bagian selatan Thailand, pantai Selatan Burma, pulau Singapura, Borneo pesisir termasuk Brunei, Kalimantan Barat, dan Sarawak dan Sabah pesisir, dan pulau-pulau kecil yang terletak antara lokasi ini yang secara kolektif dikenal sebagai Alam Melayu. Lokasi ini sekarang merupakan bagian dari negara modern Malaysia, Indonesia, Singapura, Brunei, Burma dan Thailand.

2. Motivasi

Menurut Moh. Alifuddin dan Masyhur Razak dalam konteks wirausaha, motivasi berfungsi membentuk minat. Sejauh mana minat seseorang melakoni wirausaha, motivasi menjadi penentunya. Ketiadaan motivasi membuat seseorang malas bertindak, bahkan untuk hal kecil sekalipun. Apalagi dalam urusan wirausaha, membutuhkan motivasi yang tinggi. ${ }^{2}$

3. Wirausaha

Menurut Daryanto dan Aris Dwi Cahyono, wirausaha berasal dari dua kata wira artinya berani, utama, mulia. Usaha berarti kegiatan bisnis komersil maupun non komersil. Jadi wirausaha diartikan secara harfiah sebagai hal-hal yang menyangkut keberanian seseorang untuk melakukan kegiatan bisnis maupun non bisnis secara mandiri. ${ }^{3}$

4. Usaha Mikro Kecil dan Menengah

Kementerian Koperasi dan UKM mengelompokkan UKM menjadi tiga kelompok berdasarkan total asset total penjualan tahunan, dan status usaha dengan kriteria sebagai berikut:

a. Usaha Mikro adalah kegiatan ekonomi rakyat berskala kecil dan bersifat tradisional dan informal dalam arti belum terdaftar, belum tercatat, dan belum berbadan hukum. Hasil penjualan bisnis tersebut, paling banyak 100 juta rupiah.

${ }^{2}$ Moh. Alifuddin dan Masyhur Razak, Kewirausahaan; Strategi Membangun Kerajaan Bisnis, (Jakarta: MAGNAScipt Publishing, 2015) hlm. 96.

3 Daryanto dan Aris Dwi Cahyono, Kewirausahaan (Penanaman Jiwa Kewirausahaan), (Yogyakarta: Penerbit Gava Media, 2013) hlm. 3. 
b. Usaha Kecil adalah kegiatan ekonomi rakyat yang memenuhi kriteria berikut:

1) Usaha yang memiliki kekayaan bersih paling banyak 200 juta rupiah, tidak termasuk tanah dan bangunan tempat usaha.

2) Usaha yang memiliki penjualan tahunan paling banyak 1 milyar rupiah.

3) Usaha yang berdiri sendiri, bukan perusahaan atau cabang perusahaan yang dimiliki, dikuasai, atau terafiliasi, baik langsung maupun tidak langsung dengan usaha menengah dan skala besar.

4) Berbentuk badan usaha yang dimiliki perorangan, badan usaha yang tidak berbadan hukum atau badan usaha yang berbadan hukum, termasuk koperasi.

c. Usaha menengah adalah kegiatan ekonomi rakyat yang memenuhi kriteria berikut:

1) Usaha yang memiliki kekayaan bersih lebih dari 200 juta rupiah, dan paling banyak 10 milyar rupiah, tidak termasuk tanah dan bangunan usaha.

2) Usaha yang berdiri sendiri, bukan anak perusahaan atau cabang perusahaan yang dimiliki, dikuasai, dan terafiliasi, baik langsung maupun tidak langsung dengan usaha menengah atau skala besar.

3) Berbentuk usaha yang dimiliki perorangan, badan usaha yang tidak berbadan hukum, termasuk koperasi. ${ }^{4}$

\section{E. Kajian Teori}

\section{Budaya Melayu}

\section{a. Definisi Budaya Melayu}

Agar tidak terjadi pemaknaan yang bias mengenai budaya Melayu, maka harus dipahami pemaknaan masing-masing kata tersebut terlebih dahulu. Kata yang pertama yaitu budaya. Definisi budaya sangat beragam pemaknaannya. Baik pemaknaan yang dirumuskan oleh para sarjana sosial Eropa maupun dari Indonesia sendiri. Ada dua sarjana antropologi yaitu: A.L Kroeber dan C. Kluchohn (1950) yang pernah mengumpulkan sebanyak mungkin definisi tentang faham kebudayaan yang termaktub dalam banyak

${ }^{4}$ Zulkarnain, Kewirausahaan; Startegi Pemberdayaan Usaha Kecil Menengah dan Penduduk Miskin, (Yogyakarta: Adicita Karya Nusa, 2016) Hlm. 126-127. 
buku dan yang berasal dari banyak pengarang dan sarjana. Terbukti ada 160 macam definisi tentang kebudayaan yang kemudian dianalisis dicari intinya dan diklasifikasikan dalam berbagai golongan, dan kemudian hasil penyelidikan itu diterbitkan dalam suatu kitab bernama: "Culture A Critical Review of Concept and Devinitions".

Adapun ahli antropologi yang memberikan definisi tentang kebudayaan secara sistematis dan ilmiah adalah E.B Tylor (1981) dalam buku yang berjudul: "Primitive Culture", bahwa kebudayaan adalah keseluruhan kompleks, yang di dalamnya terkandung ilmu pengetahuan yang lain, serta kebiasaan yang didapat manusia sebagai anggota masyarakat.

Klukhohn dan W.H. Kelly mencoba merumuskan definisi tentang kebudayaan sebagai hasil tanya jawab dengan para ahli antropologi, sejarah; hukum, psychology yang implicit, explicit, rasional, irasional terdapat pada setiap waktu sebagai pedoman yang potensial bagi tingkah laku manusia. ${ }^{5}$

Menurut antoropolog Indonesia Koentjaraningrat, kebudayaan berasal dari kata bhuddhayah (Sansakerta) berarti budi, akal. Dalam bahasa Inggris disebut culture, dari akar kata colere (mengolah, mengerjakan), cult (memuja). Istilah yang sangat dekat hubungannya dengan kebudayaan adalah peradaban. Yang secara etimologis berasal dari kata adab (Arab). Dalam bahasa Inggris disebut civilization, dari kata civilisatie (Latin). Baik adab maupun civilisatie berarti sopan santun, halus. Sebagai bagian kebudayaan, peradaban dengan demikian adalah puncak-puncak kebudayaan itu sendiri, seperti karya seni dan karya-karya ilmu pengetahuan lainnya, khususnya yang digunakan untuk tujuantujuan positif. ${ }^{6}$

Menurut Cliffort Geertz sebagaimana dikutip oleh Sugeng Pujileksono, kebudayaan adalah sesuatu yang dengannya kita memahami dan memberi makna pada hidup kita. Kebudayaan mengacu pada suatu pola makna-makna yang diwujudkan dalam symbol-simbol yang diturunalihkan secara historis, suatu sistem gagasan-gagasan yang diwarisi yang diungkapkan dalam bentuk-

\footnotetext{
${ }^{5}$ Kluckhohn, Clyde, The Study of Culture, Chapter V of The Policy Siences, (Edited by Daniel Lerner and Harold D. Laswell),(New York: Standford Unibersity Press, 1951), hlm.

${ }^{6}$ Koentjaraningrat, Pengantar Antropologi (Jakarta: Aksara Baru, 1974), hlm. 80.
} 
bentuk simbolik yang dengannya manusia menyampaikan, melestarikan, dan mengembangkan pengetahuan mereka mengenai sikap dan pendirian mereka terhadap kehidupan. ${ }^{7}$

Sebagaimana dikutip oleh Djoko Widagho dkk, bahwa Djojodiguno dalam bukunya "Asas-asas Sosiologi" mengatakan bahwa kebudayaan "atau budaya" adalah daya dari budi, yang berupa cipta, karsa dan rasa. ${ }^{8}$

Cipta: kerinduan manusia untuk mengetahui rahasia segala hal yang ada dalam pengalamannya, yang meliputi pengalaman lahir dan batin. Hasil cipta berupa ber bagai ilmu pengetahuan.

Karsa: kerinduan manusia untuk menginsyafi tentang hal "sangkan paran". Dari mana manusia sebelum lahir (= sangkan), dan ke mana manusia sesudah mati (=paran). Hasilnya berupa norma-norma keagamaan/kepercayaan. Timbullah bermacammacam agama, karena kesimpulan manusiapun bermacam-macam pula.

Rasa: kerinduan manusia akan keindahan, sehingga menimbulkan dorongan untuk menikmati keindahan. Manusia merindukan keindahan dan menolak keburukan/kejelekan. Buah perkembangan rasa ini terjelma dalam bentuk berbagai norma keindahan yang kemudian menghasilkan macam kesenian.

Selanjutnya, kita membahasa makna kata "Melayu". Makna Melayu yang dimaksud di sini adalah sebagai etnis. Dalam Wikipedia dijelaskan, bahwa suku Melayu adalah sebuah kelompok etnis dari orang-orang Austronesia terutama yang menghuni Semenanjung Malaya, Sumatra bagian timur, bagian selatan Thailand, pantai Selatan Burma, pulau Singapura, Borneo pesisir termasuk Brunei, Kalimantan Barat, dan Sarawak dan Sabah pesisir, dan pulau-pulau kecil yang terletak antara lokasi ini yang secara kolektif dikenal sebagai Alam Melayu. Lokasi ini sekarang merupakan bagian dari negara modern Malaysia, Indonesia, Singapura, Brunei, Burma dan Thailand.

Perbedaan Etnis Melayu dengan etnis lainnya dapat dilihat dari wataknya. Menurut Mohd. Daud Kadir dalam buku "Masyarakat Melayu Riau dan Kebudayaannya" watak orang

\footnotetext{
${ }^{7}$ Sugeng Pujileksono, Pengantar Antropologi; Memahami Realitas Sosial Budaya, (Malang: Intrans Publishing, 2015), hlm. 25.

${ }^{8}$ Djoko Widagho, dkk (2003:20)
} 
melayu diantaranya: sifat merendah diri, sifat pemalu atau penyegan, sifat suka damai atau toleransi, sifat sederhana, sifat sentimentil dan riang, dan sifat mempertahankan harga diri. ${ }^{9}$

Dari paparan di atas dapat disimpulkan bahwa budaya Melayu merupakan hasil akal budi atau renungan orang melayu berdasarkan cipta, karsa dan rasa yang menghasilkan karya seni, sastra, ilmu pengetahuan dan lain-lain.

\section{b. Unsur-Unsur Budaya Melayu}

Ketika kita membicarakan kebudayaan, maka ia sangat luas sehingga disebut sebagai memiliki nilai-nilai universal. Sebagai semesta budaya dunia Koentjaraningrat membedakannya menjadi tujuh jenis, yaitu: a) mata pencaharian (pertanian, peternakan, sistem produksi), b) peralatan (pakaian, rumah, senjata, alat-alat produksi), c)sistem kemasyarakatan (sistem kekerabatan, organisasi politik) d) bahasa (lisan dan tulisan), e) kesenian (seni lukis, seni suara, seni sastra), f) sistem pengetahuan (kealaman, sosial, humaniora) dan g) religi (agama, kepercayaan, mitos). ${ }^{10}$

Berbeda jenis bentuk kebudayaan yang dipaparkan oleh Honingmann dan para antropolog lain membedakannya menjadi tiga kempleks, yaitu: a) kompleks benda-benda sebagai hasil karya, b) kompleks aktivitas dan tindakan berpola, dan c) kompleks ide, gagasan, nilai, dan norma. Jenis pertama adalah semua bentuk bena-benda sebagai hasil keterampilan manusia, jenis kedua, adalah semua bentuk hubungan sosial, sedangkan jenis ketiga merupakan fakta mental, semua ide dan pikiran manusia. ${ }^{11}$

Dalam karya berjudul Universal Categories of Culture C. Kluckhohn merupakan ahli antropologi pertama yang merumuskan tujuh unsur budaya. ${ }^{12}$ Diantaranya adalah:

1) Peralatan dan perlengkapan hidup manusia (pakaian perumahan, alat-alat rumah tangga, senjata, alat-alat produksi, transportasi dan sebagainya);

2) Mata pencaharian hidup dan sistem-sistem ekonomi (pertanian peternakan, sistem produksi, sistem distribusi dan

\footnotetext{
${ }^{9}$ Mohd. Daud Kadir dalam buku “Masyarakat Melayu Riau dan Kebudayaannya” 1986, HIm. 516.

${ }^{10}$ Koentjaraningrat, Pengantar Antropologi (Jakarta: Aksara Baru, 1974), hlm. 82-83.

${ }^{11}$ Honingmann (1959: 11-12).

${ }^{12}$ C. Kluckhohn, Universal Categories of Culture (1953: 507-523)
} 
sebagainya);

3) Sistem kemasyarakatan (sistem kekerabatan, organisasi politik, sistem hukum, sistem perkawinan);

4) Bahasa (lisan maupun tertulis);

5) Kesenian (seni rupa, seni suara, seni gerak, dan sebagainya);

6) Sistem pengetahuan;

7) Religi (sistem kepercayaan)

Dari teori di atas dapat kita temukan unsur-unsur budaya Melayu yang meliputi:

1) Teknologi dan perlengkapan hidup

2) Mata pencaharian hidup (ekonomi)

3) Organisasi kemasyarakatan

4) Bahasa

5) Kesenian

6) Ilmu pengetahuan

7) Upacara keagamaan

\section{c. Ciri-ciri Kepribadian Orang Melayu}

Menurut Mohd. Daud Kadir dalam buku Masyarakat Melayu dan Budaya Melayu dalam Perubahan, ciri-ciri kepribadian orang Melayu sebagai berikut: ${ }^{13}$

1) Sifat Merendah

Sifat merendah merupakan sifat yang menjadi tuntutan utama dalam pergaulan orang Melayu. Orang yang selalu merendah berarti tahu diri dan sadar diri. Sifat ini tercermin pada sikap yang tertib, sopan dan hormat. Sikap-sikap tersebut tampak pada gerak-gerik dan tutur-bahasanya, terutama bila berhadapan dengan kaum kerabat atau anggota masyarakat yang lebih tua, bahkan terhadap orang asing. Sikap merendah tidak sama dengan sikap menghina-hina diri. Dengan sikap merendah, seseorang justru menjaga martabat (harga diri). Orang Melayu tidak mau dibenci masyarakat karena sikap dan tingkah-laku atau tuturbahasa yang tidak memperhatikan martabat diri. Sikap itu menunjukkan bahwa seseorang tidak tahu diri dan tidak tahu diuntung. Sifat merendah tampak jelas dalam pepatah Melayu.

${ }^{13}$ Mohd. Daud Kadir, Masyarakat Melayu dan Budaya Melayu dalam Perubahan (2016: 478486). 
Bercakap biar ke bawah-bawah

Mandi biar ke hilir-hilir

Jangan bawa sifat ayam jantan

Tapi bawalah sifat ayam betina

\section{Kalau pergi ke rantau orang}

Sikap merendah orang Melayu tidak hanya ditujukann kepada orang yang lebih tua, orang besar, pemuka adat, dan alim ulama, tetapi juga ditujukan kepada penghuni alam sekelilingnya. Oleh karena itu, jika seseorang melewati tempat angker, ia akan merendah dengan berkata, "Tabik Datuk, anak cucu numpang lalu”. Menurut orang Melayu, dengan merendah, ia akan selamat. Seseorang yang takut seorang diri di laut atau di hutan, ia akan berkata, "Tabik Datuk, jangan ganggu, anak cucu mencari makan".

Nama Melayu sering dikaitkan dengan sifat orangnya yang merendah, melayu-layukan diri seperti bunga atau daun yang layu, karena bunga yang kelopaknya layu pasti melempai atau terkulai ke bawah. Lawan dari sifat merendah adalah sifat yang suka menonjolkan diri, sombong, serta merasa serba pandai. Sifat-sifat ini paling dibenci orang Melayu. Orang Melayu tidak boleh telajak kata, tidak boleh hidung tinggi, tidak boleh hidup mengganjil, tidak boleh menunjuk pandai, tidak boleh berjalan mendada, dan tidak boleh songkok senget. Pendeknya, tidak boleh sombong dan besar cakap. Sifat merendah juga tampak saat orang Melayu berkata mengajak tamunya makan, "Silahkan jemputlah makan Encik. Tak adaapa-apa, makan tak belauk”. Padahal hidangan yang disajikan penuh dengan lauk-pauk. Jika mengajak tamunya singgah ke rumah, orang Melayu akan berkata, "Singgahlah Encik ke gubuk kami yang buruk ini". Padahal rumahnya cukup besar dan perabotnya komplit. Kalau ingin berbicara, mereka selalu berkata, "Terlebih dahulu saya minta maaf".

2) Sifat Pemalu atau Penyegan

Sifat pemalu juga bertolak dari sifat tahu diri, sadar diri, tahu diuntung, dan harga diri. Sifat pemalu merupakan sifat yang 
menjaga harga diri (martabat). Orang yang tidak tahu malu berarti tidak tahu diri dan tidak menghargai diri sendiri. Sifat pemalu tercermin dalam sikap dan tingkah-laku, seperti segan meminta bantuan, segan menonjolkan diri, segan mengadukan kesusahan, segan mengambil muka, segan berebut (tamak), segan mendahului orang tua, dan sebagainya. Oleh kerena itu, orang Melayu tampak acuh tak acuh. Bagi yang tidak mengenal watak orang Melayu, tentu berpendapat bahwa orang Melayu kurang berambisi atau kurang bergairah. Oleh karena sifat pemalunya, orang Melayu tidak mau ditegur, dimaki, dan dicerca di hadapan orang banyak, dihina di hadapan orang banyak, dipermalukan di hadapan orang, dan dihina tanpa sebab.

Oleh karena itu, jika bergurau dengan orang Melayu harus berhati-hati jangan sampai ia merasa malu di hadapan orang, karena bila tersinggung, malu atau merasa dihina (diruntuhkan air mukanya) di hadapan orang banyak, maka sifat segannya akan hilang. Bila sudah demikian, orang Melayu akan bereaksi dengan kasar untuk mempertahankan harga diri.

3) Sifat Suka Damai atau Toleransi

Orang Melayu tahu diri. Ia selalu menghargai orang lain, sebagaimana menghargai dirinya sendiri. Oleh karena itu, ia selalu terbuka dan berlapang dada. Setiap orang yang datang ke kampong halamannya selalu diberi pertolongan. Mereka beranggapan, orang tidak boleh tidur di jalan atau minum di sumur. "Biar rumah sempit, tapi hati lapang". Orang yang dapat menghargai orang lain adalah orang yang berhati mulia. Kebaikan hati akan meningkatkan harga atau martabat diri, sekaligus martabat kampung halamannya.

Akibat dari sifat toleransi ini, orang Melayu sangat senang betolak ansur, tidak cerewet atau banyak cing-cong, dan gampang berurusan. "Cincai-cincailah", kata orang Cina. Sifat suka bertolak ansur dan tidak cerewet itu menyebabkan orang Melayu suka mengalah, karena orang Melayu tidak mau ribut dan berselisih paham, yang akan menyebabkan harga dirinya luntur.

4) Sifat Sederhana

Orang Melayu selalu berfikir sederhana. Mereka tidak mau memikirkan suatu hal yang rumit dan sulit. Hidup selalu dilihat 
dari segi kesederhanaan, sederhana dalam pergaulan, memiliki harta, memakai pakaian dan perhiasan, berkata-kata, ketika bersuka ria, dalam cita-cita, dan sederhana dalam berusaha mencari rezeki. Sifat kesederhanaan ini juga berpangkal dari sifat tahu diri dan sadar diri. Orang Melayu sadar, bahwa hidup di dunia ini hanya sementara, segala isi dunia adalah milik Tuhan, hidup yang berlebihan tidak akan membuat hidup bahagia, dan hidup bahagia bukan pada harta, tetapi tertanam dalam hati. Pandangan hidup itu menyebabkan orang Melayu tenang, tidak tergesa-gesa, tidak tamak, tidak serakah, serta tidak berlombalomba mencari harta dan kedudukan.

Sifat sederhana menyebabkan orang Melayu tidak memiliki skala besar dalam berusaha dan bersaing dengan orang lain yang datang ke daerah Melayu. Sikap ini juga merupakan salah satu kerisauan cendekiawan Melayu, sebab orang Melayu abad ini tidak lagi berhadapan dengan kehidupan serba lamban dan sederhana. Orang Melayu harus melihat kembali kenyataankenyataan yang terjadi di luar dirinya. Orang Melayu harus berpartisipasi aktif memacu diri dalam era science dan teknologi yang memerlukan cara berpikir lebih future oriented.

Pandangan orang Melayu yang penulis nilai negative adalah pandangan bahwa kemiskinan merupakan warisan keturunan yang tidak dapat diubah. Pandangan ini terlihat dalam pepatah yang berbunyi "Rezeki secupak tak akan dapat jadi segantang”. Dalam syari dikatakan.

Jangan banyak piker-memikir

Takdir tak dapat dimungkir

Nasib nak miskin tentulah fakir

Bolehlah tadbir menyalahi takdir

Rezeki secupak sudah terbentang

Ke mana dikejar tak dapat digantang

Nasib berhutang mesti berbutang

Janji nak malang, malanglah datang

Berdasarkan pandangan ini, penulis berpendapat bahwa orang Melayu kurang bergairah untuk kaya. Pepatah lain yang 
selalu didengungkan oleh orang tua berbunyi "Surga bagi orang kafir di dunia ini. Surga bagi kita orang Melayu yang beragama Islam di akhirat". Dengan ajaran ini, memperbaiki hidup seolaholah tidak ada gunanya. Apalagi berlomba-lomba berebut harta serta berebut pangkat dan kedudukan, karena semua itu bukan untuk orang Melayu. Oleh karena itu, orang Melayu kelihatan seperti orang yang malas berusaha, malas mencari yang lebih banyak, dan malas memperbaiki taraf hidup. Mereka puas dengan hidup sederhana.

5) Sifat Sentimentil dan Riang

Konsekuensi dari sifat tahu diri dan sadar akan harga diri menjadikan orang Melayu sangat sentimental. Oleh karena mereka tahu akan kekurangan dan derajatnya dalam stratifikasi sosial, maka mereka selalu menekan perasaan. Keinginan dan hasratnya ditahan agar harga dirinya tidak hilang. Untuk menyalurkan gejolak perasaannya, mereka mengungkapkannya dalam bentuk lagu-lagu sedih, serta dalam nada-nada dan rentak yang sentimental. Akan tetapi mereka tidak larut dalam kesedihan yang tidak berkesudahan. Kesedihan dan kemalangan juga disalurkan dengan rentak dan nada gembira, seperti tercermin dalam rentak dan lagu-lagu berirama joget, Patampatam, mainang, dan Zapin. Orang Melayu sadar bahwa meratapi kesedihan tidak akan mengubah nasib yang sudah ditakdirkan. "Apa guna kita bersedih, lebih baik kita bersuka ria". Inilah satu imbangan dari sifat sentimental yang mewarnai corak watak kepribadian orang Melayu.

6) Sifat Mempertahankan Harga Diri

Di atas telah diuraikan sifat orang Melayu yang baik dan menyenangkan. Sifat-sifat yang menyenangkan itu selalu terpancar dalam setiap interaksi sosial. Dalam interaksi sering terjadi kemacetan komunikasi yang disebabkan oleh ketidakcocokan watak yang menyertai orang yang sedang berkomunikasi. Kemacetan komunikasi itu sering terjadi karena tidak adanya sikap saling menghargai. Apabila salah seorang yang sedang berkomunikasi merasa harga dirinya hilang, maka ia akan merasa tersinggung. Dalam keadaan tersinggung, ia akan mengambil sikap protes dengan cara memutuskan hubungan. Sikap ini dikenal dengan istilah merajuk. 
Merajuk berarti menutup diri untuk membicarakan masalah-masalah yang menyebabkan perasaaannya tersinggung. Sikap merajuk itu diperlihatkan oleh orang Melayu sebagai tanda tidak setuju terhadap sikap, tingkah laku, dan pandangan orang yang menyinggung perasaannya. Apabila sikap merajuk yang diperlihatkan tidak dihargai, bahkan diremehkan, maka ia akan mengambil sikap menjauhkan diri. Kadang-kadang ia pindah ke kampung atau negeri lain. Menjauhkan diri bertujuan untuk menghindarkan pertemuan dengan orang-orang yang telah menyinggung perasaannya. Sikap merajuk atau menjauhkan diri diambil, apabila ia merasa tak perlu memperpanjang persoalan yng kurang berarti. Tidak ada artinya bersikeras terhadap hal-hal yang kurang berarti demi memepertahankan harga diri. Namun demikian, apabila dalam interaksi terjadi pencemaran yang menjatuhkan harga diri seseorang, maka hilangnya harga diri itu akan dijawab dengan sikap amuk atau mengamuk.

Amuk atau mengamuk ialah suatu sikap untuk membela harga diri yang telah dicemarkan oleh seseorang. Harga diri dinilai tercemar apabila seseorang dipermalukan dan tidak mudah dihapuskan dalam waktu singkat. Perbuatan-perbuatan yang dipandang amat memalukan seseorang antara lain anak perempuannya dicemarkan orang, istrinya dilarikan orang, istrinya serong, dan kaum kerabatnya dihina orang. Dengan kata lain, sikap amuk timbul bila ia merasa dirinya telah dipercundangi atau dicabar orang. Akan tetapi, tidak semua hal tersebut menimbulkan sikap amuk, karena sikap amuk adalah suatu sikap paling akhir yang dapat dilakukan. Apabila telah memutuskan untuk mengamuk demi membela harga dirinya, ia harus mendahului dengan suatu sumpah (sesumbar). Sesumbar atau sumpah bertujuan untuk menimbulkan semangat, membuatkan tekad, menambah kekuatan, dan sekaligus mengumumkan kepada masyarakat bahwa sikap itu telah menjadi keputusan yang tak boleh ditarik lagi. Dengan sesumbar berarti seseorang telah memilih jalan akhir untuk memulihkan harga dirinya, yang berarti juga memutuskan segala hubungan dengan dunia dan masyarakat. Tekad amuk hanya mempunyai dua pilihan yang semuanya negative, yaitu mati atau masuk penjara. 
Oleh karena itu, sebelum memutuskan sikap amuk, seseorang harus kembali pada sikap tahu diri dan sadar diri dengan cara mempertimbangkan segala akibat yang ditimbulkan oleh amuk. Ia harus mempertimbangkan dirinya, anak istrinya, keluarganya, sanak saudaranya, dan sebagainya. Apabila memutuskan amuk, berarti ia hanya bertekad untuk mati atau menderita di penjara.

Tekad untuk mati ini menyebabkan cara berpikir, sikap, dan Perubahan itu menyebabkan seseorang menjadi liar, kasar,bengis, tidak peduli, tidak terkontrol, dan bertekad membunuh untuk memuaskan naluri yang paling buas. Dalam keadaan seperti itu, jiwa orang tersebut menjadi abnormal, hilang keseimbangan, dan pandangannya tidak jernih. Ia disebut naik pitam. Dalam hatinya bersemi marah dan tekad membinasakan. Dalam keadaan seperti itu, ia tidak lagi dapat membedakan siapa lawan dan siapa kawan. Sikap ini menjadi lebih gila apabila korban telah jatuh. Untuk menghalanginya, ia harus dihindari dan dibinasakan. Oleh karena itu, sikap amuk amat jarang terjadi. Bila seseorang telah sesumbar dan senjata telah diasah atau dicabut, maka ia harus melaksanakan, dan jika tidak, ia akan disebut sebagai seorang pengecut.

Seseorang yang telah menjadi pengecut, harga dirinya akan lenyap, sehingga sesumbar dan menarik senjata sangat jarang dilakukan. Orang lebih suka bersikap sabar atau mengalah. Orang kemudian berkesimpulan bahwa orang Melayu bersifat sabar atau suka mengalah, karena dengan sikap ini ia dapat mempertahankan harga dirinya. Sikap amuk selalu dihindarkan, karena sikap ini paling tidak disukai oleh orang Melayu. Sikap ini sesungguhnya merupakan kompleksitas kepribadian orang Melayu yang bersifat irasional, tidak human, sebagai sifat kontras dari sifat-sifat lain yang luwes dan menyenangkan.

\section{Motivasi Berwirausaha}

a. Definisi Motivasi

Motivasi berasal dari kata motif yang berarti suatu keadaan dalam pribadi orang yang mendorong individu untuk melaksanakan aktivitas tertentu guna mencapai suatu tujuan. Motif, dalam bahasa Inggrisnya "Motive", berasal dari kata "Motion", berarti gerak atau 
bergerak. Maka motivasi dipandang sebagai dorongan mental yang menggerakkan dan mengarahkan prilaku manusia atas dasar kebutuhan. Dalam motivasi, terkandung adanya keinginan yang mengaktifkan, menggerakkan, menyalurkan, dan mengarahkan sikap dan prilaku individu. ${ }^{14}$

Motivasi merupakan proses psikologis yang mendasar, dan merupakan salah satu unsur yang dapat menjelaskan prilaku seseorang. Motivasi merupakan salah satu factor penentu dalam pencapaian tujuan. Motivasi berhubungan dengan dorongan atau kekuatan yang berada dalam diri manusia. Motivasi berada dalam diri manusia yang tidak terlihat dari luar. Motivasi menggerakkan manusia untuk menampilkan tingkah laku kea rah pencapaian suatu tujuan tertentu. ${ }^{15}$

Menurut Daryanto dan Aris Dwi Cahyono, wirausaha berasal dari dua kata wira artinya berani, utama, mulia. Usaha berarti kegiatan bisnis komersil maupun non komersil. Jadi wirausaha diartikan secara harfiah sebagai hal-hal yang menyangkut keberanian seseorang untuk melakukan kegiatan bisnis maupun non bisnis secara mandiri. ${ }^{16}$

\section{b. Faktor-faktor yang Mempengaruhi Motivasi}

Menurut Siagian sebagaimana dikutip oleh Basrowi, motivasi seseorang sangat penting dan dipengaruhi oleh faktor, baik yang bersifat internal maupun eksternal ialah sebagai berikut:

1) Faktor Internal

a) Persepsi seorang mengenai diri sendiri

b) Harga diri

c) Harapan pribadi

d) Kebutuhan

e) Keinginan

f) Kepuasan

g) Prestasi yang dihasilkan

2) Faktor Eksternal

${ }^{14}$ Basrowi, Kewirausahaan untuk Perguruan Tinggi, (Bogor: Penerbit Ghalia Indonesia, 2014), hlm. 65.

15 Yuyus Suryana dan Kartib Bayu, Kewirausahaan; Pendekatan Karakteristik Wirausahawan Sukses, (Jakarta: Kencana, 2011), hlm. 98.

16 Daryanto dan Aris Dwi Cahyono, Kewirausahaan (Penanaman Jiwa Kewirausahaan), (Yogyakarta: Penerbit Gava Media, 2013) hlm. 3. 
a) Jenis dan sifat pekerjaan

b) Kelompok kerja dimana seseorang berbagi

c) Organisasi itu sendiri

d) Situasi lingkungan pada umumnya ${ }^{17}$

Menurut Kaswan dan Ade Sadikin Akhyadi, kewirausahaan dimotivasi oleh banyak factor, yang dapat dikategorikan menjadi:

1) Karakteristik kepribadian

2) Pemanfaatan waktu luang (leisure), dan

3) Semangat menjadi relawan (volunteerism)

\section{c. Motivasi Seseorang untuk Berwirausaha ${ }^{18}$}

Menurut Leonardus, sebagaimana dikutip oleh Basrowi, motivasi seseorang untuk menjadi wirausahaan, antara lain sebagai berikut: ${ }^{19}$

1) Laba. Dapat menentukan berapa laba yang dikehendaki, keuntungan yang diterima, dan berapa yang akan dibayarkan kepada pihak lain atau pegawainya.

2) Kebebasan. Bebas mengatur waktu, bebas, dari supervisi, bebas aturan, main yang menekan/intervensi, dan bebas dari aturan budaya organisasi/perusahaan

3) Impian personal. Bebas mencapai standar hidup yang diharapkan, lepas dari rutinitas kerja yang membosankan, karena harus mengikuti visi, misi, impian orang lain. Imbalan untuk menentukan nasib/visi, misi, dan impiannya sendiri.

4) Kemandirian. Memiliki rasa bangga, karena dapat mandiri dalam segala hal, seperti permodalan, mandiri dalam pengelolaan/manajemen, mandiri dalam pengawasan, serta menjadi manajer terhadap dirinya sendiri.

\section{F. Konsep Operasional}

\section{Kepribadian Orang Melayu (X)}

1) Sifat Merendah

- Tahu diri dan sadar diri

${ }^{17}$ Basrowi, Kewirausahaan untuk Perguruan Tinggi, hlm. 65-66

18 Kaswan dan Ade Sadikin Akhyadi, Social Entrepreneurship; Mengubah Masalah Sosial Menjadi Peluang Usaha (Bandung: Alfabeta, 2015), hlm. 41.

${ }^{19}$ Basrowi, Kewirausahaan untuk Perguruan Tinggi, (Bogor: Penerbit Ghalia Indonesia, 2014), hlm. 67. 
- Tertib, sopan dan hormat

2) Sifat Pemalu atau Penyegan

- Menjaga harga diri (martabat)

- Segan meminta bantuan dan Segan mengadukan kesusahan

- Segan menonjolkan diri (pamer)

- Segan mengambil muka

- Segan berebut (tamak)

- Segan mendahului orang tua

- Sifat pemalu adalah tidak mahu ditegur, dimaki dan dicerca di hadapan orang banyak

3) Sifat Suka Damai atau Toleransi

- Menghargai orang lain

- Terbuka dan berlapang dada

- Suka mengalah, tidak mau rebut dan berselisih paham

4) Sifat Sederhana

- Tidak mau memikirkan hal yang rumit dan sulit

- Kesederhanaan dalam pergaulan, memiliki harta, pakaian dan perhiasan

- Sederhana dalam berusaha mencari rezeki

- Tidak berlomba-lomba mencari harta dan kedudukan

- Tidak memiliki skala besar dalam berusaha dan bersaing dengan orang lain yang datang ke daerah Melayu

5) Sifat Sentimentil dan Riang

- Tahu akan kekurangan dan derajatnya dalam strafikasi sosial

- Tidak mau meratapi kesedihan, karena tidak akan merubah nasib yang sudah ditakdirkan

6) Sifat Mempertahankan Harga Diri

- Sikap protes dengan cara merajuk

- Menjauhkan/mengasingkandiri

- Mengamuk jika ada pencemaran yang menjatuhkan harga dirinya

- Apabila memutuskan amuk, berarti dia bertekad untuk membunuh untuk memuaskan naluri yang paling buas (naikpitam)

- Bersumpah demi membela harga dirinya

\section{Motivasi Berwirausaha (Y)}

1) Laba

- Dapat menentukan berapa laba yang dikehendaki 
- Keuntungan yang diterima

- Berapa yang akan dibayarkan kepada pihak lain atau pegawainya

2) Kebebasan

- Bebas mengatur waktu

- Bebas dari supervisi

- Bebas aturan main yang menekan/intervensi

- Bebas dari aturan budaya organisasi/perusahaan

3) Impian Personal

- Bebas mencapai standar hidup yang diharapkan

- Lepas dari rutinitas kerja yang membosankan, karena harus mengikuti visi, misi dan impian orang lain

- Imbalan untuk menentukan nasib/visi, misi dan impiannya sendiri

4) Kemandirian

- Memiliki rasa bangga, karena dapat mandiri dalam segala hal. Seperti permodalan

- Mandiri dalam pengelolaan/manajemen

- Mandiri dalam pengawasan, serta menjadi manajer terhadap dirinya sendiri

\section{G. Penelitian Terdahulu yang Relevan}

Penelitian ini bukan merupakan penelitian pertama kali dilakukan. Ada beberapa penelitian sebelumnya yang membahas tentang wirausaha. Di antaranya:

a. Jurnal internasional yang ditulis oleh Kamisan Gadar and Nek Kamal Yeop Yunus dengan judul "The Influence of Personality And SocioEconomic Factors on Female Entrepreneurship Motivations in Malaysia”. Penelitian ini menguji latar belakang pengusaha wanita Malaysia, faktor motivasi, karakteristik dan persepsi pribadi pada perilaku kewirausahaan. Sampel keseluruhan terdiri dari 685 perempuan pengusaha di Malaysia. Pekerjaan lapangan dilakukan antara Februari dan Juni 2007 dan mencakup semua 13 negara di Malaysia yang dibagi menjadi 5 zona. Sebuah 76 item tertutup yang terstruktur digunakan untuk mengumpulkan data. Analisis statistik secara keseluruhan dibagi menjadi dua kelompok terpisah, yaitu deskriptif dan statistik inferensial. Yang pertama meneliti bagaimana responden memvariasikan tanggapan mereka untuk setiap pertanyaan. Yang terakhir meneliti faktor apa 
paling penting untuk memotivasi pengusaha perempuan dan korelasi antara pendapatan kewirausahaan dan pribadi mereka. Hasilnya menunjukkan bahwa, mayoritas responden adalah orang Melayu dan lebih dari setengah dari mereka berusia di atas 40 tahun dan memiliki setidaknya tiga anak. Menariknya, sekitar 70 persen responden memiliki kualifikasi sekunder, sementara 10 persen adalah lulusan universitas dan 20 persen sisanya memiliki pendidikan dasar. Meskipun tidak semuanya responden berasal dari keluarga pengusaha, mereka berhasil mendapatkan lebih banyak uang setelah mereka bersatu. Hasil analisis lebih lanjut menunjukkan tiga temuan utama. Pertama, analisis korelasi menunjukkan bahwa pendapatan pengusaha berkorelasi sangat lemah dengan tingkat pendidikan dan pengalaman. Di sisi lain, tidak ada korelasi antara pendapatan kewirausahaan dan faktor usia. Kedua, dengan pengecualian faktor usia, Pendapatan pengusaha berbeda secara signifikan menurut pengalaman dan pendidikan ditunjukkan melalui ANOVA satu arah. Terakhir, analisis faktor mengungkapkan bahwa sembilan faktor itu relatif signifikan dari set asli dari 12 faktor. Akhirnya, hanya 20 yang dipilih dari 63 item terkandung. Persepsi lingkungan ekonomi dalam hal teknologi dan informasi adalah faktor yang paling relevan. Ini diikuti oleh etika kerja dan nilai-nilai manajemen sebagai karakteristik pribadi utama bagi pengusaha perempuan. $^{20}$

b. Jurnal yang ditulis oleh Mumuh Mulyana dan Ratih Puspitasari dengan judul "Analisis Faktor-Faktor yang Membentuk Minat Berwirausaha Siswa SMK di Kota Bogor". Penelitian tersebut menghasilkan bahwa Faktor Kepribadian memberi pengaruh nyata terhadap terbentuknya minat berwirausaha para siswa SMK Kota Bogor. Para Siswa SMK di Kota Bogor memandang bahwa untuk berwirausaha dibutuhkan kepribadian yang sesuai dengan dinamika kewirausahaan yang senantiasa bersahabat dengan ketidakpastian, perjuangan, dan pengambilan resiko. Sikap-sikap yang dibutuhkan untuk membangun Kepribadian Berwirausaha para siswa SMK adalah antara lain: (a) Sikap Bertanggung jawab, (b) Sikap Mampu mengambil resiko, (c) Sikap keyakinan besar bisa sukses, (d) Sikap mampu menghadapi hambatan dan (e) Sikap mampu menghadapi kritik. Di samping itu,

${ }^{20}$ Kamisan Gadar and Nek Kamal Yeop Yunus, The Influence of Personality And SocioEconomic Factors on Female Entrepreneurship Motivations in Malaysia, Vol.5 No. 1 January 2009 (Malaysia: International Review of Business Research Papers, 2009) h. 149-162 
Faktor lain yang mempengaruhi minat berwirausaha para siswa SMK di Kota Bogor secara tidak langsung adalah Faktor Kebutuhan akan Prestasi (O: 0,266; |O/STERR|: 2,249) dan Faktor Efikasi Diri (O: 0,350; |O/STERR|: 2,920). Kedua faktor tersebut berpengaruh terhadap Minat Berwirausaha melalui faktor Kepribadian. Faktor Kebutuhan akan Prestasi terdiri dari sikap Percaya akan kemampuan diri sendiri, kemampuan mencapai cita-cita, kemampuan mencapai prestasi tinggi serta kemampuan mencapai prestasi seperti orang lain. Sedangkan faktor Efikasi Diri terdiri dari sikap menyukai tantangan, bisa mengambil pelajaran dari kegagalan, tidak suka mencari kambing hitam, berorientasi sukses dan kreatif. ${ }^{21}$

c. Jurnal yang ditulis oleh Erfikas Widiyatnoto dengan judul "Pengaruh Jiwa Kewirausahaan dan Budaya Keluarga Terhadap Minat Berwirausaha pada Siswa SMKN 1 Wonosari dan SMKN 2 Wonosari di Kabupaten Gunung Kidul". Penelitian tersebut menunjukan bahwa: (1) Terdapat pengaruh positif dan signifikan jiwa kewirausahaan terhadap minat berwirausaha pada siswa SMKN 1 dan SMKN 2 Wonosari di Gunungkidul, SMKN 1 Wonosari dengan $t_{\text {hitung }}>t_{\text {tabel }}$ $(5,207>1,686)$, koefisien determinan sebesar 41,6 \% dan $\mathrm{Y}=0,099+$ $0,962 \mathrm{X} 1$. Sedangkan SMKN 2 Wonosari mempunyai $t_{\text {hitung }}>t_{\text {tabel }}$ $(2,993>1,686)$, koefisien determinan sebesar $19,1 \%$ dan $\mathrm{Y}=1,412+$ $0,579 \mathrm{X} 1$, (2) Terdapat pengaruh positif dan signifikan budaya keluarga terhadap minat berwirausaha pada siswa SMKN 1 dan SMKN 2 Wonosari di Gunungkidul, SMKN 1 Wonosari mempunyai $t_{\text {hitung }}>t_{\text {tabel }}$ $(5,144>1,686)$, koefisien determinan sebesar $41 \%$ dan $\mathrm{Y}=1,579+$ $0,599 \mathrm{X} 2$. Sedangkan SMKN 2 Wonosari mempunyai $t_{\text {titung }}>t_{\text {tabel }}$ $(3,050>1,686)$, sedang koefisien determinan sebesar 19,7 \% dan $\mathrm{Y}=$ $2,335+0,354$ X2, (3) Terdapat pengaruh positif dan signifikan jiwa kewirausahaan dan budaya keluarga secara bersama-sama terhadap minat berwirausaha pada siswa SMKN 1 dan SMKN 2 Wonosari di Gunungkidul, SMKN 1 Wonosari mempunyai $t_{\text {hitung }}>t_{\text {tabel }}$ ( $t_{\text {hitung }} \mathrm{X} 1$, $\mathrm{X} 2$ sebesar $=4,135$ dan 4,069>t tabel: 1,687$)$, sedangkan harga koefisien determinasi $59,7 \%$ dan $\mathrm{Y}=-0,578+0,698 \mathrm{X} 1+0,430 \mathrm{X} 2$. Sedangkan SMKN 2 Wonosari mempunyai $t_{\text {hitung }}>t_{\text {tabel }}\left(t_{\text {hitung }} \mathrm{X} 1\right.$, X2 sebesar $=$ 2,141 dan 2,211 > tabel: 1,687), sedangkan harga koefisien determinasi

21 Mumuh Mulyana dan Ratih Puspitasari, Analisis Faktor-Faktor yang Membentuk Minat Berwirausaha Siswa SMK di Kota Bogor (Bogor: Sekolah Tinggi Ilmu Ekonomi Kesatuan, 2013) 
sebesar 28,5\% dan $\mathrm{Y}=1,042+0,423 \mathrm{X} 1+0,263 \mathrm{X} 2$. (4) Terdapat perbedaan jiwa kewirausahaan, budaya keluarga dan minat berwirausaha antara siswa SMKN 1 (putri) dan SMKN 2 (putra) Wonosari di Gunungkidul, dengan hasil jiwa kewirausahaan: thitung $>$ $t_{\text {tabel }}(3,418>1,991)$, budaya keluarga: $t_{\text {hitung }}>t_{\text {tabel }}(3,624>1,991)$, dan minat berwirausaha: thitung $>t_{\text {tabel }}(4,142>1,991) .{ }^{22}$

d. Skripsi yang ditulis oleh Bayu Andri Nugraha dengan judul "Pengaruh Jiwa Kewirausahaan Dan Budaya Keluarga Terhadap Minat Berwirausaha (Studi Kasus Pada Mahasiswa Ums Program Pendidikan Pkn Angkatan 2012). Penelitian tersebut menghasilkan (1) Bahwa jiwa kewirausahaan berpengaruh positif dan signifikan terhadap minat berwirausaha pada mahasiswa FKIP PKn Universitas Muhammadiyah Surakarta variabel $37,8 \%$. (2) Bahwa budaya keluarga berpengaruh positif dan signifikan terhadap minat berwirausaha pada mahasiswa FKIP PKn Universitas Muhammadiyah Surakarta variabel 62,2 \%.(3) Bahwa jiwa kewirausahaan dan budaya keluarga secara bersama-sama berpengaruh positif dan signifikan terhadap minat berwirausaha pada mahasiswa FKIP PKn Universitas Muhammadiyah Surakarta variabel $85,5 \% .^{23}$

Jika dilihat dari penelitian sebelumnya, belum ada yang meneliti tentang pengaruh keperibadian orang Melayu terhadap motivasi berwirausaha pada Usaha Mikro Kecil Menengah.

\section{H. Hipotesis}

Menurut hipotesis merupakan jawaban sementara yang masih harus dibuktikan kebenarannya melalui penelitian Hipotesis dalam penelitian ini adalah: ${ }^{24}$

Ha: Apakah ada pengaruh yang signifikan antara keperibadian orang melayu terhadap motivasi berwirausaha pada Usaha Mikro Kecil Menengah masyarakat Bengkalis.

Ho: Tidak ada ada pengaruh yang signifikan antara keperibadian orang

${ }^{22}$ Erfikas Widiyatnoto, Pengaruh Jiwa Kewirausahaan dan Budaya Keluarga Terhadap Minat Berwirausaha pada Siswa SMKN 1 Wonosari dan SMKN 2 Wonosari di Kabupaten Gunung Kidul, (Yogyakarta: Universitas Negeri Yogyakarta, 2013).

${ }^{23}$ Bayu Andri Nugraha, Pengaruh Jiwa Kewirausahaan Dan Budaya Keluarga Terhadap Minat Berwirausaha (Studi Kasus Pada Mahasiswa Ums Program Pendidikan Pkn Angkatan 2012), (Surakarta: Universitas Muhammadiyah Surakarta, 2014).

${ }^{24}$ Sugiyono, Metode Penelitian Bisnis, (Bandung: Alfabeta, 2006). 
melayu terhadap motivasi berwirausaha pada Usaha Mikro Kecil Menengah masyarakat Bengkalis.

\section{Lokasi dan Waktu Penelitian}

Penelitian ini dilakukan di Kecamatan Bengkalis, Kabupaten Bengkalis. Sedangkan waktu penelitian ini dilakukan dari bulan September sampai dengan bulan Desember 2018.

\section{J. Subjek dan Objek Penelitian}

Subjek penelitian adalah orang melayu. Sedangkan objek penelitian ini adalah pengaruh kepribadian terhadap motivasi berwirausaha.

\section{K. Populasi dan Sampel Penelitian}

Populasi penelitian ini adalah seluruh masyarakat Kecamatan Bengkalis dengan populasi 93 orang dan sampel 75 orang. Data yang diambil merupakan data dari Dinas Koperasi UMKM Kabupaten Bengkalis. Pengambilan sampel digunakan Rumus Solvin.

$$
\begin{aligned}
& \mathrm{n}=\mathrm{N} /\left(1+\left(\mathrm{N} \times \mathrm{e}^{2}\right)\right) \\
& \mathrm{n} \quad: \text { jumlah sampel } \mathrm{N}: \text { jumlah populasi } \\
& \mathrm{E} \quad: \text { batas toleransi kesalahan (error tolerance) } \\
& \mathrm{n}=93 /\left(1+\left(93 \times 0,05^{2}\right)\right) \\
& \mathrm{n}=93 /(1+(93 \times 0,0025)) \\
& \mathrm{n}=93 / 1,2325 \\
& \mathrm{n}=75
\end{aligned}
$$

\section{Teknik Pengumpulan Data}

Teknik pengumpulan data yang digunakan dalam penelitian ini adalah:

1. Wawancara (interview) yang dilakukan dengan pihak yang berkompeten atau yang berwenang untuk memberikan informasi dari keterangan sesuai yang dibutuhkan peneliti.

2. Kuesioner (questioner) yaitu pengumpulan data dengan cara menyebarkan kuesioner yang telah disajikan sedemikian rupa kemudian meminta jawaban kepada responden sesuai dengan tujuan penelitian.

\section{M.Jenis dan Sumber Data}


Adapun jenis dan sumber data yang penulis perlukan dalam penelitian ini adalah sebagai berikut:

1. Data primer yaitu data yang diperoleh langsung dari responden yang berhubungan dengan objek penelitian, yaitu kepribadian orang melayu dan motivasi berwirausaha di Kecamatan Bengkalis.

2. Data sekunder yaitu data dan informasi dalam bentuk jadi yang telah dimiliki oleh Pemerintah Kabupaten Bengkalis yang bisa di Akses atau diambil dari Badan Pusat Statistik Kabupaten Bengkalis.

\section{N. Uji Kualitas Data}

Untuk menetukan batas-batas kebenaran ketepatan alat ukur (kuesioner) suatu indikator variabel penelitian dapat dilakukan dengan cara sebagai berikut:

1. Uji Validitas (Test Of Validity)

Uji validitas menunjukan sejauh mana alat ukur benar-benar cocok atau sesuai sebagai alat ukur yang diinginkan. Pengujian validitas di lakukan untuk menguji apakah hasil jawaban dari kusioner oleh responden benar-benar cocok digunakan dalam penelitian ini. Hasil penelitian yang valid apabila terdapat kesamaan antara data yang dikumpulkan dengan sesungguhnya terjadi objek yang diteliti. Instrument valid berarti alat ukur yang digunakan untuk mendapatkan data (mengukur) valid. Valid berarti instrument tersebut dapat digunakan untuk mengukur apa yang seharusnya diukur.

2. Uji Reliabilitas(Test Of Realiability)

Uji Realibilitas adalah tingkat kesetabilan suatu alat pengukur dalam mengukur suatu gejala atau kejadian. Pengujian Realibilitas dilakukan untuk mengetahui apakah hasil jawaban dari kusioner oleh responden benar-benar stabil dalam mengukur suatu gejala atau kejadian. Instrument yang reabilitas adalah instrument yang digunakan beberapa kali untuk mengukur objek yang sama akan menghasilkan data yang sama. $^{25}$

${ }^{25}$ Ghozali,Imam, Aplikasi Analisis Multivariate dengan Program SPSS edisi ketiga, 2006, hlm. 


\section{Uji Normalitas}

Uji normalitas bertujuan untuk menguji apakah dalam model regresi, variabel pengganggu (residual) memiliki destribusi normal, seperti diketahui, uji $\mathrm{t}$ dan uji $\mathrm{F}$ mengasumsikan bahwa nilai residual mengikuti distribusi normal. Deteksi normalitas dilakukan dengan melihat penyebaran data (titik) pada sumbu diagonal dari grafik. Jika data menyebar disekitar garis diagonal, maka model regresi memenuhi asumsi Normalitas. (Ghozali: 2006)

\section{O. Teknik Analisis Data}

Dalam menganalisa data yang diperoleh dari responden maka penulis menggunakan metode secara analisis kuantitatif dan analisa statistik yang deskriptif yaitu menyusun data yang sudah ada sedemikian rupa kemudian dianalisa dan dihubungkan dengan teori-teori yang mendukung dan kemudian ditarik suatu kesimpulan.

Dengan menganalisa data penulis menggunakan metode deskriptif kuantitatif.

1. Metode Deskriptif Kuntitatif

Metode deskriptif adalah penganalisaan data melalui metode merumuskan, menguraikan dan menginterpretasikan berdasarkan telaah pustaka yang terdapat dalam skripsi dan literature sebagai referensi penilitian ini, untuk kemudian ditarik sebuah kesimpulan.

Dalam penelitian ini perhitungan dilakukan dengan menggunakan program SPSS 20.0 dan hasilnya akan disajikan dalam bab pembahasan. Untuk mengukur pengaruh dari variabel bebas (kepribadian orang melayu) dan variabel terikat (minat kewirausahaan), akan digunakan metode ananlisis regrensi linier sederhana.

2. Uji Regresi Linier Sederhana

Analisis regresi linier sederhana adalah suatu metode analisa yang digunakan untuk menentukan ketetapan prediksi dari pengaruh yang terjadi antara variabel independen $(\mathrm{X})$ terhadap variabel dependen (Y). Formula untuk Regresi sederhana adalah sebagai berikut:

$\mathrm{Y}=\mathrm{a}+\mathrm{bX}+\mathrm{e}$ 
Dimana: $\mathrm{Y}=$ Kepribadian Orang Melayu (Variabel dependen)

$\mathrm{X}=$ Motivasi Kewirausahaan (Variabel independen)

$\mathrm{a}, \mathrm{b}=$ Konstanta

$e=$ error

\section{P. Gambaran Umum Responden}

Penelitian inidilakukan dengan membagikan kuesioner kepada sampel yang merupakan pengusaha pada Usaha Kecil dan Menengah di Kecamatan Bengkalis. Kuesioner ini terbagi dalam 2 bagian,, yang pertama adalah bagaimana respon Pengusaha tentang kepribadiannya dan yang kedua adalah respon pengusaha mengenai motivasinya dalam melakukan usahanya. Gambaran mengenai pengusaha yang menjadi responden dalam penelitian ini akan dijelaskan dalam kelompok usaha dan jenis kelamin Responden.

Tabel V.1 Data UMKM menurut Kriteria

\begin{tabular}{|c|c|c|}
\hline Kriteria UMKM & Jumlah & \% \\
\hline Mikro & 68 & 91 \\
\hline Kecil & 7 & 9 \\
\hline Menengah & - & - \\
\hline Total & 75 & 100 \\
\hline
\end{tabular}

Sumber: Data Olahan

Berdasarkan tabel di atas, dari 75 responden yang menjadi objek peneltian 68 usaha termasuk dalam kriteria Mikro (91\%) dan 7 usaha termasuk dalam kriteria usaha kecil (9\%) serta tidak ada usaha yang termasuk dalam kriteria menengah.

Tabel V.2: Data Responden Menurut Jenis Kelamin

\begin{tabular}{|c|c|c|}
\hline Kriteria UMKM & Jumlah & \% \\
\hline Pria & 48 & 64 \\
\hline Wanita & 27 & 36 \\
\hline Total & 75 & 100 \\
\hline
\end{tabular}

Sumber: Data Olahan 
Berdasarkan Tabel dari 75 Orang yang menjadi sampel Penelitian 48 orang adalah berjenis kelamin perempuan (64\%), 27 orang adalah berjenis kelamin laki-laki (36\%).

\section{Q. Pernyataan Pengusaha Mengenai Kepribadian}

\section{Tabel V. 3}

Data mengenai Analisis Pernyataan Terhadap Kepribadian

\begin{tabular}{|c|c|c|c|c|c|c|c|c|}
\hline PERNYATAAN & STS & TS & $\mathrm{C}$ & S & SS & Total & $\begin{array}{l}\text { Rata- } \\
\text { rata }\end{array}$ & Kesimpulan \\
\hline $\begin{array}{l}\text { Saya bersikap sopan dan hormat ketika } \\
\text { berhadapan dengan kaum kerabat atau } \\
\text { anggota masyarakat yang lebih tua. }\end{array}$ & 48 & 24 & 3 & 0 & 0 & 339 & 4,52 & sangat baik \\
\hline $\begin{array}{l}\text { Saya selalu merendah diri dan sadar diri } \\
\text { dalam pergaulan sehari - hari }\end{array}$ & 23 & 39 & 10 & 3 & 0 & 307 & 4,09 & baik \\
\hline $\begin{array}{l}\text { Orang yang tidak tahu malu berarti tidak } \\
\text { tahu diri dan tidak menghargai diri sendiri. }\end{array}$ & 35 & 29 & 3 & 6 & 2 & 308 & 4,11 & baik \\
\hline $\begin{array}{l}\text { Saya malu dan segan meminta bantuan } \\
\text { serta mengadukan kesusahan }\end{array}$ & 16 & 30 & 8 & 20 & 1 & 265 & 3,53 & baik \\
\hline $\begin{array}{l}\text { Saya segan menonjolkan diri (pamer), } \\
\text { mengambil muka dan berebut (tamak). }\end{array}$ & 30 & 31 & 9 & 2 & 3 & 308 & 4,11 & baik \\
\hline $\begin{array}{l}\text { Saya selalu mengutamakan orang tua } \\
\text { untuk di dahulukan. }\end{array}$ & 46 & 28 & 1 & 0 & 0 & 345 & 4,60 & sangat baik \\
\hline $\begin{array}{l}\text { Saya selalu menghargai orang lain seperti } \\
\text { menghargai diri sendiri }\end{array}$ & 40 & 28 & 6 & 1 & 0 & 332 & 4,43 & sangat baik \\
\hline $\begin{array}{l}\text { Saya selalu terbuka dan berlapang dada } \\
\text { kepada setiap orang yang datang }\end{array}$ & 22 & 38 & 10 & 4 & 1 & 301 & 4,01 & baik \\
\hline $\begin{array}{l}\text { Saya Lebih baik mengalah dalam } \\
\text { berselisih paham }\end{array}$ & 20 & 26 & 21 & 8 & 0 & 283 & 3,77 & kurang baik \\
\hline $\begin{array}{l}\text { Kesederhanaan dalam pergaulan, } \\
\text { memiliki harta, memakai pakaian dan }\end{array}$ & 28 & 33 & 10 & 3 & 1 & 309 & 4,12 & baik \\
\hline $\begin{array}{l}\text { Saya selalu Berusaha sederhana dalam } \\
\text { mencari rezeki }\end{array}$ & 23 & 38 & 12 & 2 & 0 & 307 & 4,09 & baik \\
\hline $\begin{array}{l}\text { Saya tidak suka berlomba-lomba mencari } \\
\text { harta dan kedudukan }\end{array}$ & 21 & 45 & 8 & 1 & 0 & 311 & 4,15 & baik \\
\hline $\begin{array}{l}\text { Saya tahu akan kekurangan berinteraksi } \\
\text { dalam masyarakat }\end{array}$ & 7 & 43 & 16 & 9 & 0 & 273 & 3,64 & baik \\
\hline $\begin{array}{l}\text { Saya tidak larut dalam kesedihan yang } \\
\text { tidak berkesudahan }\end{array}$ & 21 & 31 & 15 & 6 & 2 & 288 & 3,84 & baik \\
\hline $\begin{array}{l}\text { Saya akan merajuk sebagai tanda tidak } \\
\text { setuju terhadap sikap, tingkah laku dan } \\
\text { pandangan orang yang menyinggung } \\
\end{array}$ & 8 & 16 & 20 & 19 & 12 & 214 & 2,85 & kurang baik \\
\hline $\begin{array}{l}\text { Saya menjauhkan diri bertujuan untuk } \\
\text { menghindarkan pertemuan dengan orang- } \\
\text { orang yang telah menyinggung perasaan }\end{array}$ & 7 & 7 & 21 & 31 & 9 & 197 & 2,63 & kurang baik \\
\hline Saya akan mengamuk ketika hilangnya & 10 & 7 & 18 & 23 & 17 & 195 & 2,60 & kurang baik \\
\hline$\sum$ Rata - rata X & & & & & & 4882 & 65,09 & \\
\hline Rata - rata X & & & & & & 287,2 & 3,82902 & baik \\
\hline
\end{tabular}


Dari table di atas dapat di simpulkan bahwa kepribadian orang melayu di Kecamatan Bengkalis mempunyai kepribadian yang baik denga rata - rata 3,82 .

\section{R. Pernyataan Pengusaha Mengenai Motivasi}

Tabel V. 31: Data Pernyataan Mengenai Motivasi

\begin{tabular}{|c|c|c|c|c|c|c|c|c|}
\hline PERNYATAAN & STS & $\mathrm{TS}$ & $\mathrm{C}$ & $\mathrm{S}$ & SS & Total & $\begin{array}{l}\text { Rata- } \\
\text { rata }\end{array}$ & Kesimpulan \\
\hline $\begin{array}{l}\text { Saya dapat menentukan berapa } \\
\text { keuntungan (laba) yang saya } \\
\text { kehendaki }\end{array}$ & 18 & 38 & 13 & 4 & 2 & 291 & 3,88 & baik \\
\hline $\begin{array}{l}\text { Saya dapat menentukan keuntungan } \\
\text { yang saya terima }\end{array}$ & 15 & 40 & 9 & 10 & 1 & 283 & 3,77 & baik \\
\hline $\begin{array}{l}\text { Saya dapat menentukan berapa gaji } \\
\text { yang akan dibayarkan kepada } \\
\text { karyawan }\end{array}$ & 20 & 40 & 12 & 3 & 0 & 302 & 4,03 & baik \\
\hline Saya bebas mengatur waktu & 24 & 38 & 7 & 6 & 0 & 305 & 4,07 & baik \\
\hline Saya bebas dari supervisi (pengawas) & 12 & 28 & 17 & 17 & 1 & 258 & 3,44 & baik \\
\hline $\begin{array}{l}\text { Saya bebas dari aturan main yang } \\
\text { menekan/intervensi pihak luar }\end{array}$ & 12 & 38 & 14 & 11 & 0 & 276 & 3,68 & baik \\
\hline $\begin{array}{l}\text { Saya bebas dari aturan budaya } \\
\text { organisasi/perusahaan }\end{array}$ & 12 & 28 & 16 & 15 & 4 & 254 & 3,39 & kurang baik \\
\hline $\begin{array}{l}\text { Saya bebas mencapai standar hidup } \\
\text { yang diharapkan }\end{array}$ & 23 & 37 & 10 & 5 & 0 & 303 & 4,04 & baik \\
\hline $\begin{array}{l}\text { Saya dapat lepas dari rutinitas kerja } \\
\text { yang membosankan, karena harus } \\
\text { mengikuti visi, misi dan impian orang } \\
\text { lain }\end{array}$ & 15 & 29 & 20 & 9 & 2 & 271 & 3,61 & baik \\
\hline $\begin{array}{l}\text { Saya bebas menentukan nasib/visi, } \\
\text { misi dan impian saya sendiri }\end{array}$ & 23 & 30 & 17 & 4 & 1 & 295 & 3,93 & baik \\
\hline $\begin{array}{l}\text { Saya merasa bangga, karena dapat } \\
\text { mandiri dalam segala hal. Seperti } \\
\text { permodalan }\end{array}$ & 27 & 36 & 11 & 1 & 0 & 314 & 4,19 & baik \\
\hline $\begin{array}{l}\text { Saya mandiri dalam } \\
\text { pengelolaan/manajemen }\end{array}$ & 22 & 34 & 15 & 4 & 0 & 299 & 3,99 & baik \\
\hline $\begin{array}{l}\text { Saya mandiri dalam pengawasan, } \\
\text { serta menjadi manajer terhadap diri } \\
\text { saya sendiri }\end{array}$ & 17 & 38 & 15 & 5 & 0 & 292 & 3,89 & baik \\
\hline$\sum$ Rata - rata X & & & & & & 3743 & 49,907 & \\
\hline Rata - rata X & & & & & & 287,92 & 3,839 & baik \\
\hline
\end{tabular}


Berdasarkan table di atas menunjukkan bahwa motivasi berwirausaha di Kecamatan Bengkalis dalam mengembangkan usaha UMKM termasuk dalam katagori baik.

\section{S. Uji t (t test)}

Uji ini dipakai untuk mengetahui pengaruh variabel bebas terhadap variabel terikat, berdasarkan perhitungan SPSS, maka dapat diketahui hasil koefesien regresi seperti table di bawah ini.

\section{Coefficients $^{\mathrm{a}}$}

\begin{tabular}{|c|c|c|c|c|c|c|}
\hline \multirow{2}{*}{\multicolumn{2}{|c|}{ Model }} & \multicolumn{2}{|c|}{$\begin{array}{c}\text { Unstandardized } \\
\text { Coefficients }\end{array}$} & $\begin{array}{l}\text { Standardized } \\
\text { Coefficients }\end{array}$ & \multirow[b]{2}{*}{$\mathrm{t}$} & \multirow[b]{2}{*}{ Sig. } \\
\hline & & B & Std. Error & Beta & & \\
\hline \multirow[t]{2}{*}{1} & (Constant) & 27.955 & 8.041 & & 3.477 & .001 \\
\hline & $\begin{array}{l}\text { Kepribadian } \\
\text { (X) }\end{array}$ & .336 & .123 & .305 & 2.739 & .008 \\
\hline
\end{tabular}

a. Dependent Variable: Y

Diketahui Nilai Signifikasi dari tabel di atas adalah 0,08 > 0,05 dan $t_{\text {hitung }} 2,739>t_{\text {tabel }} 1,665$, maka terdapat pengaruh kepribadian orang melayu terhadap motivasi berwirausaha dalam usaha Mikro, Kecil dan Menengah tetapi pengaruhnya tidak signifikan.

\section{T. Koefesien Korelasi Sederhana (Uji R)}

Koefesien Korelasi sederhana digunakan untuk menguji hipotesis hubungan antara dua variabel dan untuk melihat kuat lemahnya hubungan antara dua variabel.

\begin{tabular}{|c|c|c|c|c|c|c|c|c|c|}
\hline \multicolumn{10}{|c|}{ Model Summaryb } \\
\hline \multirow[b]{2}{*}{ Model } & \multirow[b]{2}{*}{$\mathrm{R}$} & \multirow[b]{2}{*}{ R Square } & \multirow[b]{2}{*}{\begin{tabular}{|c|} 
Adjusted R \\
Square
\end{tabular}} & \multirow[b]{2}{*}{$\begin{array}{l}\text { Std. Error of } \\
\text { the Estimate }\end{array}$} & \multicolumn{5}{|c|}{ Change Statistics } \\
\hline & & & & & $\begin{array}{c}\text { R Square } \\
\text { Change }\end{array}$ & F Change & df1 & $\mathrm{df} 2$ & $\begin{array}{l}\text { Sig. F } \\
\text { Change }\end{array}$ \\
\hline 1 & $.305^{a}$ & .093 & .081 & 5.60203 & .093 & 7.501 & 1 & 73 & .008 \\
\hline
\end{tabular}
a. Predictors: (Constant), $X$
b. Dependent Variable: $Y$ 
Berdasarkan hasil ouput SPSS di atas dapat disimpulkan bahwa Kofisiensi korelasi sederhana bernilai 305 atau 30,5\% , Hal ini menggambarkan bahwa tingkat hubungan variabel $\mathrm{X}$ dan $\mathrm{Y}$ dalam kriteria tidak erat.

\section{U. Analisis Regresi Sederhana}

\section{Coefficients $^{\mathrm{a}}$}

\begin{tabular}{|c|c|c|c|c|c|c|}
\hline \multirow{2}{*}{\multicolumn{2}{|c|}{ Model }} & \multicolumn{2}{|c|}{ Unstandardized Coefficients } & Standardized & \multirow[b]{2}{*}{$\mathrm{t}$} & \multirow[b]{2}{*}{ Sig. } \\
\hline & & B & Std. Error & Beta & & \\
\hline 1 & (Constant) & 27.955 & 8.041 & & 3.477 & .001 \\
\hline & $\mathrm{X}$ & .336 & .123 & .305 & 2.739 & .008 \\
\hline
\end{tabular}

a. Dependent Variable: Y

Untuk mencari hubungan antara variabel bebas yaitu kepribadian (X) terhadap variabel terikat yaitu Motivasi (Y) dipakai teknik analisis data Regresi Linear Sederhana. Berdasarkan hasil pengolahan maka diperoleh data-data sebagai berikut:

$$
\begin{aligned}
& \mathrm{Y}= \mathrm{a}+\mathrm{bX} \\
& \mathrm{Y}=\text { Kepribadian Orang Melayu (Variabel dependen) } \\
& \mathrm{X}=\text { Motivasi Kewirausahaan (Variabel independen) } \\
& \mathrm{a}, \mathrm{b}=\text { Konstanta } \\
& \mathrm{Y}=27,955+336 \mathrm{X}
\end{aligned}
$$

\section{Kesimpulan}

1. Orang Melayu di Kecamatan Bengkalis mempunyai kepribadian yang baik, hal ini di tunjukkan dengan nilai rata-rata pada tabel $\mathrm{X}$ (independen) sebesar 3,82.

2. Motivasi berwirausaha dalam Usaha Mikro Kecil dan Menengah (UMKM) pada oang melayu termasuk dalam katagori baik ini ditunjukkan denga tabel Y (dependen) sebesar 3,83.

3. Terdapat pengaruh kepribadian orang melayu terhadap motivasi berwirausaha dalam usaha Mikro, Kecil dan Menengah tetapi 
pengaruhnya tidak signifikan. Nilai Signifikasi dari tabel di atas adalah $0,08>0,05$ dan $t_{\text {hitung }} 2,739>t_{\text {tabel }} 1,665$.

\section{W.Saran}

Penelitian ini dapat ditindak lanjuti dengan penelitian selanjutnya dengan memperluas kajian permasalahan yang terjadi pada dunia kewirusahaan dalam masyarakat khususnya di Kabupaten Bengkalis, sehingga menjadi tambahan solusi untuk kedepannya dalam meningkatkan kesejahteraan masyarakat serta menjadi acuan pengambilan keputusan bagi stake holders. 


\section{Daftar Pustaka}

Basrowi, Kewirausahaan untuk Perguruan Tinggi, (Bogor: Penerbit Ghalia Indonesia, 2014)

Daryanto dan Aris Dwi Cahyono, Kewirausahaan (Penanaman Jiwa Kewirausahaan), (Yogyakarta: Penerbit Gava Media, 2013)

Edi Suharto, Kebijakan Sosial sebagai kebijakan public, (Bandung: Alfabeta 2008)

Ghozali,Imam, Aplikasi Analisis Multivariate dengan Program SPSS edisi ketiga, 2006

Badan penerbitan Bisnis. Alfabeta.Bandung Honingman J.J., The World of Man, (New York: Routledge, 1959)

Kaswan dan Ade Sadikin Akhyadi, Social Entrepreneurship; Mengubah Masalah Sosial Menjadi Peluang Usaha (Bandung: Alfabeta, 2015)

Kluckhohn, Clyde, The Study of Culture, Chapter V of The Policy Siences,

(Edited by Daniel Lerner and Harold D. Laswell),(New York:

Standford Unibersity Press, 1951)

Koentjaraningrat, Pengantar Antropologi (Jakarta: Aksara Baru, 1974) , dkk, Masyarakat Melayu dan Budaya Melayu dalam

Perubahan, Cet. I, (Yogyakarta: Adicita Karya Nusa, 2016)

dkk, Masyarakat Melayu Riau dan

Kebudayaannya,(Pekanbaru : Pemerintah Propinsi Daerah Tingkat I

Riau, 1986)

Kroeber dan Kluckhohn, The Concept of Culture: A Critical Review Definitions, Vol. XLI, (Harvard: Paper of the Pesbody Museum Harvard University, 1950)

Majalah Antropology at Day, (Chicago: A. L. Kroeber editor, University Press, 1953) 
Moh. Alifuddin dan Masyhur Razak, Kewirausahaan; Strategi Membangun Kerajaan Bisnis, (Jakarta: MAGNAScipt Publishing, 2015)

Sugeng Pujileksono, Pengantar Antropologi; Memahami Realitas Sosial Budaya, (Malang: Intrans Publishing, 2015).

Sugiyono, Metode Penelitian Bisnis, (Bandung: Alfabeta, 2006).

Suryana, Yuyus dan Kartib Bayu, Kewirausahaan; Pendekatan Karakteristik Wirausahawan Sukses, (Jakarta: Kencana, 2011).

Taylor, Edward B, Primitive Culture, Vol. II, pp. 1-6 Jhon Muray, (London: 1981).

UU Hamidy, Perangkap Demokrasi dan Bunga Kehidupan, Cet. I, (Pekanbaru: Bilik Kreatif Press, 2013).

Zulkarnain, Kewirausahaan; Startegi Pemberdayaan Usaha Kecil Menengah dan Penduduk Miskin, (Yogyakarta: Adicita Karya Nusa, 2016).

https://bengkaliskab.bps.go.id

https://wikipedia.org/wiki/Suku_Melayu 